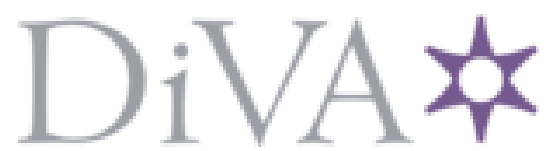

http://www.diva-portal.org

\title{
Postprint
}

This is the accepted version of a paper published in Refugee Survey Quarterly. This paper has been peer-reviewed but does not include the final publisher proof-corrections or journal pagination.

Citation for the original published paper (version of record):

Olivius, E. (2014)

Displacing Equality?: Women's Participation and Humanitarian Aid Effectiveness in Refugee Camps.

Refugee Survey Quarterly, 33(3): 93-117

https://doi.org/10.1093/rsq/hdu009

Access to the published version may require subscription.

N.B. When citing this work, cite the original published paper.

Permanent link to this version:

http://urn.kb.se/resolve?urn=urn:nbn:se:umu:diva-92030 


\section{DISPLACING EQUALITY? WOMEN'S PARTICIPATION AND HUMANITARIAN AID EFFECTIVENESS IN REFUGEE CAMPS}

In humanitarian aid policy and practice, the importance of women's participation is strongly emphasized. However, this article argues that women's participation has become an instrument for optimizing the efficiency and effectiveness of humanitarian operations rather than a tool for the promotion of gender equality. Drawing on the Foucauldian concept of governmentality, the article examines how women's participation is represented and employed as a means to improve the effectiveness and efficiency of humanitarian aid in two refugee camp contexts, in Bangladesh and in Thailand, and asks how such strategies affect the gendered relations of power that shape women's lives in the camps. Based on interviews with humanitarian workers, the analysis shows that programs that promote women's participation as a means for the achievement of other goals can reinforce existing gender inequalities, but also, despite their constraining effects, contribute to open up new opportunities for women. However, equality is treated as a side effect, not a goal in its own right. In conclusion, the article suggests that renewed engagement with the political project of feminism is needed to counter the depolitization and instrumentalization of gender in humanitarian aid, and bring the goals of equality and justice back in.

Keywords: women's participation, refugee camps, humanitarian aid, governmentality, neoliberalism, Bangladesh, Thailand 


\section{Introduction}

In 1990, the United nations High Commissioner for Refugees (UNHCR) released its first Policy on Refugee Women, ${ }^{1}$ signaling a move away from a gender-blind model of humanitarianism that marginalized women and ignored their needs. Since then, humanitarian gender policy and practice have evolved significantly, owing much to feminist advocacy and engagement with the international refugee regime and the wider international humanitarian community. ${ }^{2}$ However, the feminist, political goals of gender equality and social justice have often been downplayed or sidelined in humanitarian approaches to gender. Rather than a perspective for engaging with structural inequality and disadvantage, attention to "gender" too frequently merely means being attuned to differences between women and men and seeking to take them into account to design effective aid programmes. ${ }^{3}$ Gender analysis thus becomes an instrument for optimizing the efficiency and effectiveness of humanitarian operations rather than a tool for the promotion of gender equality.

The displacement of the goal of equality from humanitarian approaches to gender is well exemplified in the current emphasis on women's participation. In humanitarian aid policy and practice, women's participation in the planning and implementation of aid programmes is frequently described as an important goal, and women beneficiaries of aid are represented as essential partners in a successful humanitarian operation. The Age, Gender and Diversity Mainstreaming (AGDM) strategy of the UNHCR makes consultations with groups of refugees segregated by age and gender the basis for the operational planning of the organization, and women in particular are described as "key sources of information" in this process. ${ }^{4}$ Further, humanitarian policy discourse describes women in emergency situations as "the secret weapon to beat hunger" 5 and as "key actors in influencing the public health of the household". 6 Thus, the participation of women is not primarily represented as an issue of equality, justice or power;

\footnotetext{
${ }^{1}$ United Nations High Commissioner for Refugees (UNHCR), Policy on Refugee Women, available at http://www.unhcr.org/3ba6186810.html (last visited 9 Jan. 2014).

${ }^{2}$ D. Buscher, "Refugee Women: Twenty Years On", Refugee Survey Quarterly, 29(2), 2010, 4-20; A. Edwards, "Transitioning Gender: Feminist Engagement with International Refugee Law and Policy 1950-2010", Refugee Survey Quarterly, 29(2), 2010, 21-45.

${ }^{3}$ Edwards, “Transitioning Gender", 2010, 44-45

${ }^{4}$ UNHCR, Handbook for the Protection of Women and Girls, 2008, available at http://www.unhcr.org/47cfa9fe2.html (last visited 3 Jan. 2014), 34-38, 98.

${ }^{5}$ World Food Programme (WFP), Women and WFP: Helping Women Help Themselves, 2011, available at http://documents.wfp.org/stellent/groups/public/documents/communications/wfp232415.pdf (last visited 8 Jan. 2014).

${ }^{6}$ Inter-Agency Standing Committee (IASC), Women, Girls, Boys and Men: Different Needs, Equal Opportunities. IASC Gender Handbook in Humanitarian Action, 2006, available at http://www.humanitarianinfo.org/iasc/documents/subsidi/tf_gender/IASC $\% 20 \mathrm{Gender} \% 20 \mathrm{Handbook} \% 20 \% 28 \mathrm{Fe}$ b\%202007\%29.pdf (last visited 3 Jan. 2014), 105.
} 
rather, it is discussed in terms of the contribution it can make towards the achievement of humanitarian goals such as public health or food security. Women's participation has become a means of programme implementation rather than a way to realize the rights of refugee women and achieve gender equality.

Representations of women as key resources for the achievement of a range of ends are not unique to the field of humanitarian aid, but have become very resonant in international organizations working in different fields of global governance. In development aid, women's participation in the economy is represented as crucial to poverty eradication and sustainable development as they are assumed to be more risk-adverse, more focused on the welfare of the household and less corrupt than men. ${ }^{7}$ In peace and security, women are represented as natural peacemakers and their participation in conflict resolution and peacebuilding is strongly emphasized, most prominently in United Nations Security Council Resolution 1325, as essential to the achievement of peace, reconciliation and security. ${ }^{8}$ As these examples illustrate, representations of women as resources frequently draw on essentialist images of women and the specific capacities they are expected to bring to the table. Women's participation is seen as important because women are assumed to be able to contribute with qualities that would otherwise be lacking. ${ }^{9}$

The strategic potential as well as the dangers inherent in instrumental arguments for women's participation or equality has been debated by feminist scholars. While it is acknowledged that instrumentalism may open doors for inclusion of women in previously hostile environments, assumptions about women's nature or gender-specific qualities also limit the ways in which women can act. In addition, such essentialisms obscure the complexities of women's (and men's) lives, and there is a risk that women's participation will be forgotten as soon as it no longer contributes to the envisioned goals as it was expected to. ${ }^{10}$ However,

\footnotetext{
${ }^{7}$ S. Bessis, "International Organizations and Gender: New Paradigms and Old Habits." Signs 29(2), 2004, 633647; A.M. Goetz, "Political Cleaners: Women as the New Anti-Corruption Force?" Development and Change 38(1), 2007, 87-105; C. Jackson, "Resolving Risk? Marriage and Creative Conjugality." Development and Change 38(1), 2007, 107-129.

${ }^{8}$ E. Helms, "Women as agents of ethnic reconciliation? Women's NGOs and International Intervention in Postwar Bosnia-Herzegovina", Women's Studies International Forum 26(1), 2003, 15-33; J. El-Bushra, "Feminism, Gender, and Women's Peace Activism." Development and Change 38(1), 2007, 131-147; C. Cohn, "Mainstreaming Gender in UN Security Policy: A Path to Political Transformation?" in. S. Rai \& W. Georgina (eds.) Global Governance: Feminist Perspectives. New York:Palgrave Macmillan, 2008.

${ }^{9}$ A. Kronsell, Gender, Sex and the Postnational Defense: Militarism and Peacekeeping:Oxford University Press, $2012,66$.

${ }^{10} \mathrm{C}$. Cohn, \& C. Enloe, "A conversation with Cynthia Enloe: Feminists look at masculinity and the men who wage war", Signs 28(4), 2003, 1187-1107; A. Cornwall, E. Harrison \& A. Whitehead, "Gender Myths and Feminist Fables: The Struggle for Interpretive Power in Gender and Development", Development and Change 38(1), 2007, 1-20; E. Bjarnegård \& E. Melander, "Revisiting Representation: Communism, Women in Politics, and the Decline of Armed Conflict in East Asia", International Interactions 39(4), 2013, 558-574.
} 
whether instrumental arguments for women's participation contribute to increase women's opportunities for agency or to further constrain and marginalize them is often ambiguous and highly contextual. ${ }^{11}$ Whether humanitarian programmes that promote women's participation actually contribute to improvements in the situation of refugee women cannot be taken for granted. ${ }^{12}$ Indeed, as El-Bushra points out, expecting women to participate in new ways without decreasing their current responsibilities may simply leave refugee women with more work to do, while existing frameworks of gender difference and power remain intact. ${ }^{13}$

This study analyses how women's participation is represented and employed as a means to improve the effectiveness and efficiency of humanitarian aid in two refugee camp contexts, and asks how such strategies affect the gendered relations of power that shape women's lives in the camps. The analysis contributes to the discussion about the implications of the instrumental promotion of women's participation in global governance through an analysis of how a discourse of women-as-resources has been employed in two cases of humanitarian aid work. Moreover, focusing on the field practices of humanitarian organizations seeking to promote women's participation, the study contributes to a better understanding of the practical meaning and impact of humanitarian gender policies in the field. Drawing on interviews with humanitarian workers complemented by organizational reports and documentation, it analyses how women's participation is represented and promoted in refugee camps in Bangladesh and in Thailand. Specifically, the study examines programmes that seek to utilize women's participation to address child malnutrition in refugee camps in Bangladesh, and make distribution of food more efficient in refugee camps in Thailand. The results indicate that programmes that promote the participation of women for instrumental reasons can reinforce existing gender inequalities and gender norms, but also contribute to challenge notions of masculinity and femininity and open up new opportunities for women. However, to realize the latter possibility it is necessary to eventually broaden the discussion of women's participation beyond instrumentalism.

The paper is structured as follows. The next section situates the construction of women's participation as a resource in the context of neoliberal governmentality, which tends to submit gender issues to an economistic and depoliticized rationality that precludes a focus on issues of power and justice. It introduces governmentality as an analytical approach, and presents the

\footnotetext{
${ }^{11}$ Helms,'Women as Agents of Ethnic Reconciliation?", 2003.

${ }^{12}$ E. Fiddian-Qasmiyeh, "'Ideal' Refugee Women and Gender Equality Mainstreaming in the Sahrawi Refugee Camps: 'Good Practice' for Whom?', Refugee Survey Quarterly, 29(2), 2010, 64-84.

${ }^{13}$ J. El-Bushra. "Gender and forced migration: editorial", Forced Migration Review 9 (Gender and Displacement), 2000.
} 
material of the study. This is followed by the analysis, examining first the promotion of women's participation as a means to address child malnutrition in Bangladesh, and second the promotion of women's participation as a means to make food distribution more efficient in Thailand. The concluding section further discusses and compares the implications of the instrumental use of women's participation as a resource in these two cases.

\section{Women's participation, neo-liberalism and governmentality}

The emphasis on women's participation as a resource in humanitarian aid must be seen in the light of broader developments in the humanitarian field. In recent decades, the field of humanitarian aid has undergone a shift towards neo-liberal management strategies emphasizing accountability and efficiency. Technologies and methods for the measurement of humanitarian performance, drawing on new public management principles, have been developed as part of a process of bureaucratization of humanitarian organizations. ${ }^{14}$ Further, the delivery of aid is increasingly made conditional on the recipients' meeting "good governance" criteria for accountability and transparency. ${ }^{15}$ Moreover, participatory approaches to humanitarian aid work have been introduced as a remedy for refugee "dependency", based on the assumption that making refugees more responsible for their own welfare will make the delivery of aid more efficient. ${ }^{16}$ Participation, and especially women's participation, has become a central strategy for the government of refugees and refugee camps. ${ }^{17}$

These changes in the field of humanitarian aid can be understood as expressions of a shift towards neo-liberal governmentality. The concept of governmentality was coined by Foucault, and has since been developed by a number of social science scholars. ${ }^{18}$ As an analytical concept, governmentality denotes "the systematic thinking and knowledge that is integral to and renders possible different modes of governing". ${ }^{19}$ Thus, a governmentality

\footnotetext{
${ }^{14}$ M. Barnett, "Humanitarianism Transformed", Perspectives on politics 3(4), 2005, 723-740: 730.

${ }^{15}$ M. Dillon \& J. Reid. "Global governance, liberal peace, and complex emergency", Alternatives: Global, Local, Political 25(1), 2000, 117-143: 120.

${ }^{16}$ R. Lippert, "Governing refugees: the relevance of governmentality to understanding the international refugee regime", Alternatives: Global, Local, Political 24(3), 1999, 295-328: 312-314.

${ }^{17}$ S. Turner, "New Opportunities: Angry Young Men in a Tanzanian Refugee Camp" in. P. Essed, G. Frerks \& J. Schrijvers (eds.), Refugees and the Transformation of Societies. Agency, Policies, Ethics and Politics. New York \& Oxford:Berghahn Books, 2004; Author 2013a (to be added).

${ }^{18}$ G. Burchell, C. Gordon \& P. Miller (eds.), The Foucault effect: studies in governmentality: with two lectures by and an interview with Michel Foucault. London:Harvester Wheatsheaf, 1991; N. Rose \& P. Miller. "Political power beyond the State: problematics of government", The British Journal of Sociology 43(2), 1992, 173-205; W. Larner \& W. Walters (eds.), Global governmentality: governing international spaces, London \& New York:Routledge, 2004; M. Dean, Governmentality: power and rule in modern society, London:Sage Publications, 2010.

${ }^{19}$ O.J. Sending \& I. B. Neumann, "Governance to Governmentality: Analyzing NGOs, States, and Power", International Studies Quarterly 50(3), 2006, 651-672: 657.
} 
perspective approaches neo-liberalism not as ideology or philosophy, but as certain practices and forms of government that operates in locally specific ways. ${ }^{20}$ Neo-liberal practices of government are underpinned by specific rationalities, or forms of thought and knowledge, that makes these practices possible. Brown argues that the central feature of neo-liberal governmentality is the extension of market logics and values to all institutions and spheres of social action. All areas of life are submitted to an economic rationality that comes to shape global institutions as well as the identity and conduct of individual subjects. ${ }^{21}$ Under this neoliberal rationality, a "business case" has been made for the implementation of gender mainstreaming in international organizations, and women's empowerment has been pursued in order to harness the "efficiency gains" to be had from investments in women's "human capital". ${ }^{22}$ Furthermore, as pointed out by Mouffe, neo-liberal government "reduces politics to a set of supposedly technical moves and neutral procedures" to be conducted by experts. ${ }^{23}$ Politics becomes an issue of implementing "best practice" or finding the "right solutions". Consequently, while gender may be articulated as a public issue in a neo-liberal frame, it becomes difficult to articulate gender in terms of power and conflict. Thus, it becomes difficult to acknowledge existing relations of power and expose them to contestation and change. ${ }^{24}$ Humanitarian gender programs informed by neo-liberal rationalities have been demonstrated to produce an instrumental and depoliticized conception of gender, where the legitimacy of programs promoting gender equality is measured by their utility for the achievement of operational goals. wherein addition, gender equality is constructed as a technical, administrative issue that requires international expertise rather than an issue of power and politics. ${ }^{25}$ However, while distinguishing these general features of neo-liberal governmentality, it is important to recognize that there are different configurations of neo-liberalism. Neo-liberalism should thus be theorized as a multi-vocal and contradictory phenomenon to enable analyses attuned to the particularities of specific neo-liberal projects, Larner argues. ${ }^{26}$

Of particular relevance to this study is the neo-liberal orientation towards governing through the "freedom" and agency of the governed subjects. Rather than shaping conduct

\footnotetext{
${ }^{20}$ Larner \& Walters, Global Governmentality, 2004, 4.

${ }^{21}$ W. Brown, Edgework: Critical essays on knowledge and politics, Princeton:Princeton University Press, 2009, 39-42.

${ }^{22}$ J. True, "Mainstreaming gender in global public policy", International Feminist Journal of Politics 5(3), 2003, 368-396: 385 .

${ }^{23}$ C. Mouffe, On the Political, London \& New York:Routledge, 2005, 106.

${ }^{24}$ M. Rönnblom, "Bending towards growth. Discursive constructions of gender equality in an era of governance and neoliberalism" in. E. Lombardo, P. Meier \& M. Verloo (eds.), The Discursive Politics of Gender Equality. Stretching, Bending and Policymaking, London \& New York:Routledge, 2009, 105-120.

${ }^{25}$ Author 2013b (to be added).

${ }^{26}$ W. Larner, "Neo-liberalism: Policy, ideology, governmentality", Studies in political economy 63, 2000.
} 
through coercion and force, neo-liberal governmentality seeks to create rational, self-regulating subjects who conduct themselves in accordance with certain norms. ${ }^{27}$ The moral autonomy of neo-liberal subjects is measured by their capacity to provide for their own needs and service their own ambitions. ${ }^{28}$ Individuals and groups not considered to possess these capabilities often become targets of interventions that seek to 'empower' them and transform them into active, self-regulating subjects. Such interventions, Dean argues, are central to neoliberal government and can be characterized as technologies of agency. Technologies of agency are practices that seek to engage the governed as active, responsible subjects who can take responsibility for their own lives. ${ }^{29}$ Participatory approaches in humanitarian aid that aim to empower, activate and responsibilize refugee recipients of aid exemplify how technologies of agency come into play in the government of subjects who, evidenced by their dependence on humanitarian aid, fail to become the neo-liberal entrepreneur of the self. ${ }^{30}$ However, in the context of humanitarian aid to refugees in camps, women and men are not targeted by humanitarian technologies of agency in the same way or to the same extent. ${ }^{31}$ Neo-liberal government does not only presuppose the existence of a generic, self-regulating subject but is reliant on particular gendered subjectivities that must be fostered through governing practices that shape the conduct of men and women in different ways. The particular emphasis on women's participation in humanitarian aid provides an opportunity to explore the dynamics of this theme, which has thus far been relatively neglected in the governmentality literature. However, feminist analyses of neo-liberal development thinking and practice have demonstrated how women, "empowered" as economic actors but still embodying feminine reproductive qualities, are particularly useful subjects of neoliberal development (Rankin 2001; Keating, Rasmussen et al. 2010; Madhok and Rai 2012). ${ }^{32}$ As this literature highlights, neoliberal projects often mobilize women's agency and participation as a resource in the achievement of goals that may ultimately not benefit women. However, in comparison to development aid, the field of humanitarian aid has received less scholarly attention both with regards to the impact of neo-liberalization and with regards to the effects of gender policies and programs.

\footnotetext{
${ }^{27}$ Dean, Governmentality, 2010, 18.

${ }^{28}$ Brown, Edgework, 2003, 42.

${ }^{29}$ Dean, Governmentality, 2010, 196-197.

${ }^{30}$ Lippert, "Governing Refugees", 1999, 309.

${ }^{31}$ Author 2013a; Author 2013b (to be added).

${ }^{32}$ K.N. Rankin, "Governing development: Neoliberalism, microcredit, and rational economic woman." Economy and Society 30(1), 2001, 18-37: C. Keating, C. Rasmussen \& R. Pooja, "The Rationality of Empowerment: Microcredit, Accumulation by Dispossession, and the Gendered Economy", Signs 36(1), 2010, 153-176; Madhok, S. and S. M. Rai. "Agency, Injury, and Transgressive Politics in Neoliberal Times." Signs 37(3), 2012, 645-669.
} 


\section{Material and analytical strategy}

This study is based on a total of 58 interviews with actors involved in humanitarian aid to Burmese refugees in Thailand and Bangladesh. The interviews were conducted by the author in 2010 and 2011. In Thailand, 32 interviews were conducted with humanitarian workers from UN agencies, NGOs, and refugee community-based organizations (CBOs) in Mae Sot and in Bangkok. In Bangladesh, 20 interviews were conducted with humanitarians working for UN agencies and NGOs in Cox's Bazar and in Dhaka. Interviews conducted during fieldwork were complemented with six telephone interviews. The humanitarian workers interviewed consisted of a mix of international and national staff members and men and women of various ages. Each interview lasted for approximately one hour. Interviews focused on humanitarian organizations' gender policies and programmes, and the meanings they attributed to gender equality as a policy goal in their work. Interviewees would often discuss efforts to increase women's participation, which is often perceived as synonymous with gender equality. However, in the interviews, women's participation was recurrently discussed in instrumental terms, as important for the achievement of a range of humanitarian goals. Conversely, women's perceived passivity or failure to participate in ways expected by humanitarian organizations was also frequently brought up and described as a problem. ${ }^{33}$ The analysis presented here is focused on two areas of humanitarian work: programmes addressing child nutrition in Bangladesh, and distribution of food in Thailand. These areas were selected because they constitute areas where women's participation was very commonly discussed as a key resource for successful humanitarian programmes in the interviews. However, they are not unique in this regards but can be seen as illustrative of broader rationalities and practices in the Bangladeshi and Thai refugee camps. Thus, a close examination of the rationalities behind, and the effects of, efforts to increase women's participation in these areas provides insights into more general patterns in how women's participation operates as a governing strategy in humanitarian aid. The interviews constitute the bulk of the empirical material, but are complemented by program reports from UN organizations and NGOs that address issues of child nutrition in Bangladesh and food distribution in Thailand.

An analysis of governmentality directs attention to the link between knowledge and government, recognizing that ways of knowing and representing a phenomenon is intrinsically

\footnotetext{
${ }^{33}$ Author 2013a (to be added).
} 
linked to, and enables, particular ways of acting upon it. ${ }^{34}$ Rose and Miller suggest that the analysis of governmentalities can be approached through two interrelated dimensions. They use the term rationalities to denote the particular forms of representation, thought and knowledge that render reality thinkable and governable, while the term technologies denote the practical techniques, methods, instruments and institutions that enable authorities to act upon the conduct of individuals and groups so as to transform it. "Rationalities and technologies, thought and intervention", according to Rose and Miller, can be thought of as "two indissociable dimensions through which one might characterize and analyse governmentalities and begin to open them up to critical judgment". ${ }^{35}$ In this study, this framework was used to structure the analysis of the material. Thus, the analytical point of departure was to identify the concrete methods, techniques or practices that are used to foster women's participation in addressing child malnutrition in Bangladesh and improving food distribution in Thailand. Secondly, the causal arguments and assumptions underlying these practices were examined. Why is women's participation assumed to contribute to particular results? What are the qualities and capacities that women are thought to contribute with? What subjectivities are women expected or encouraged to embody in order to be useful resources in humanitarian aid work? Finally, the analysis focused on the implications of these governing technologies and rationalities. What forms of agency are enabled or precluded, and how are these programs and the forms of women's participation they promote likely to impact on existing gendered relations of power? Next, the analysis of women's participation in refugee camps in Bangladesh and in Thailand, drawing on the framework of analysis outlined above, is presented.

\section{Bangladesh: women as resources against child malnutrition}

This section examines how women's participation is represented and employed as a means to address child malnutrition in refugee camps in Bangladesh. First, a brief background to the refugee situation and the current context of humanitarian aid work in the Bangladeshi camps is provided.

\subsection{Burmese refugees in Bangladesh}

\footnotetext{
${ }^{34}$ Foucault, M. "Governmentality" in. G. Burchell, C. Gordon \& P. Miller (eds.), The Foucault Effect: Studies in Governmentality: With Two Lectures by and an Interview with Michel Foucault. London:Harvester Wheatsheaf, 1991, 87-104: 102-104; Rose, N. and P. Miller. Governing the present: administering economic, social and personal life, Cambridge:Polity Press, 2008, 15

${ }^{35}$ Rose \& Miller, Governing the Present, 2008, 16
} 
The border between Arakan State in Western Burma, home of the Rohingya Muslim minority, and Eastern Bangladesh has historically been fluid. Labor migration across the border was encouraged during British colonization when both Burma and Bangladesh were administered as parts of British India. When the Japanese occupied Burma during World War Two, the Rohingyas stayed loyal to the British in exchange for a promise of an autonomous Muslim state in northern Arakan. At the end of the war the British promise was not kept, and Rohingyan aspirations to independence were not well seen by the leaders of newly independent Burma. ${ }^{36}$ After the onset of military rule, repression and discrimination of the Rohingyas increased. All military governments have since consistently denied the Rohingyas Burmese citizenship. They have been barred from military and civil service, and subject to persecution, violence, and confiscation of property. In 1977, the military conducted a registration exercise in preparation for a national census, aiming to screen out individuals considered 'foreign'. This was accompanied by extreme violence; killings, rape, and destruction of mosques. More than 200,000 Rohingyas fled to Bangladesh as a result. Bangladesh were unwilling to accept the refugees, and was forced to request assistance from the UN to handle the influx. The refugees were eventually forced to return to Burma through a repatriation exercise characterized by tactics of violence and coercion, leaving about 10,000 Rohingya dead. ${ }^{37}$ A decade later, during the unrest following the government's refusal to recognize the 1990 election results, the military turned to the Rohingyas as a scapegoat and the level of repression increased again. This caused a new mass exodus: by March 1992 nearly 270,000 refugees had fled to Bangladesh, making this one of the largest refugee flights in history. Again, the majority of refugees were eventually repatriated. Despite the involvement of the UNHCR the repatriation exercise was far from voluntary and has received massive criticism. ${ }^{38}$

Approximately 20,000 refugees managed to remain in Bangladesh after the 1994/1995 repatriation, and these now make up the majority of the 31,000 refugees living in two official refugee camps, Kutupalong and Nayapara. ${ }^{39}$ These camps are managed by the Bangladeshi

\footnotetext{
${ }^{36}$ C. Lewa, "The Rohingya: Forced Migration and Statelessness" in O. Mishra (ed.) Forced Migration in South Asian Region, Calcutta: Centre for Refugee Studies Jadavpur University; E. Pittaway, "The Rohingya Refugees in Bangladesh: A Failure of the International Protection Regime" in. H. Adelman (ed.), Protracted displacement in Asia: no place to call home. Aldershot:Ashgate Publishing, 2008, 83-106.

${ }^{37}$ M. Barnett \& M. Finnemore, "Defining Refugees and Voluntary Repatriation at UNHCR" in M. Barnett and M. Finnemore (eds.), Rules for the world: International organizations in global politics, Ithaca \& London:Cornell University Press, 2004, 73-120; Pittaway, "The Rohingya Refugees in Bangladesh", 2008. ${ }^{38}$ Lewa, The Rohingya, 2001; C. Lewa, 'We are like a Soccer Ball, Kicked by Burma, Kicked By Bangladesh!' Rohingya Refugees are Facing a New Drive of Involuntary Repatriation, Bangkok:FORUM-ASIA, 2003; Barnett \& Finnemore, "Defining Refugees", 2004; Pittaway, "The Rohingya Refugees in Bangladesh", 2008. ${ }^{39}$ Pittaway, "The Rohingya Refugees in Bangladesh", 2008; UNHCR, UNHCR Bangladesh Fact Sheet September 2013, 2013, available at http://www.unhcr.org/50001ae09.html (last visited 5 Nov. 2013).
} 
government. Humanitarian aid is provided by UN organizations such as the UNHCR and the World Food Program (WFP), and a number of international and national NGOs. However, education and health services are limited, and experiences of persecution in Burma, repeated forced repatriation movements, and lack of security and opportunities in Bangladesh have created a camp environment pervaded by fear and insecurity. ${ }^{40}$ In 2013 , the government of Bangladesh allowed Grade Six education to be provided in the camps for the first time. Previously, only primary education had been allowed. ${ }^{41}$ Although large-scale repatriation has not resumed after 1995, there has been continued pressure from Bangladeshi authorities to coerce refugees to go back, involving abuses such as false accusations and imprisonment, beatings, and confiscation of belongings and ration books. Despite this, due to continued violence and persecution in Arakan State Rohingya people have continued to flee to Bangladesh, but later arrivals have been denied refugee status and access to the two official camps. As a result, an estimated 200, 000 unregistered Rohingya live in villages in Eastern Bangladesh and in camp-like settlements in the vicinity of the official refugee camps. ${ }^{42}$ The Bangladeshi government does not authorize provision of humanitarian aid to unregistered refugees outside the official camps. ${ }^{43}$ Furthermore, several thousands of the refugees in the official camps are unregistered and do not receive food rations. In 2011, there were five thousand people in the two official camps who were not recognized as refugees by the government. ${ }^{44}$ Outbreaks of violence in Western Burma in 2012 displaced an estimated 115,000 people, mostly Rohingya, inside Burma. Thousands who have tried to cross the border to Bangladesh have been pushed back by the Bangladeshi government, citing national security concerns, host fatigue and fear of a new mass influx of refugees. ${ }^{45}$

\subsection{Child malnutrition and women's participation in the Bangladeshi refugee camps}

Despite the provision of food assistance and basic health care services by humanitarian organizations, malnutrition rates in the Bangladeshi camps have remained high, especially among children. ${ }^{46}$ In 2012, thirteen per cent of children below five years of age were acutely

\footnotetext{
${ }^{40}$ Pittaway, "The Rohingya Refugees in Bangladesh", 2008; UNHCR, UNHCR Bangladesh Fact Sheet, 2013.

${ }^{41}$ UNHCR, UNHCR Bangladesh Fact Sheet, 2013.

${ }^{42}$ Lewa, C. "We are like a Soccer Ball", 2003; UNHCR, UNHCR Bangladesh Fact Sheet, 2013.

${ }^{43}$ Refugees International, Bangladesh - The Silent Crisis, available at

http://www.refugeesinternational.org/policy/field-report/bangladesh-silent-crisis (last visited 5 Nov. 2013).

${ }^{44}$ Interview 30, NGO Bangladesh, Cox’s Bazar 3 Mar. 2011.

${ }^{45}$ UNHCR, UNHCR Bangladesh Fact Sheet, 2013.

${ }^{46}$ WFP \& UNHCR, Report of the WFP-UNHCR Joint Assessment Mission 15th - 24th June 2008, 2008, available at http://documents.wfp.org/stellent/groups/public/documents/ena/wfp190341.pdf (last visited 8 Jan. 2014); WFP \& UNHCR, Report of the WFP-UNHCR Joint Assessment Mission, Bangladesh 30th May-14th June 2010, 2010, available at http://www.refworld.org/pdfid/4cdd31062.pdf (last visited 8 Jan. 2014).
} 
malnourished. ${ }^{47}$ To prevent and address malnutrition, a "life cycle approach" is employed, meaning that all children between six months and two years, adolescent girls, and pregnant and lactating women receive supplementary feeding in addition to the general food ration provided to registered refugees. Further, acutely malnourished children are referred to a therapeutic feeding program and their growth and nutritional status is monitored more closely. ${ }^{48}$ The prevalence of acute malnutrition is highest in children between six months and two years, as this is the period when increasing amounts of solid foods should be introduced into the diet of the child. Pregnant and lactating mothers receive supplementary feeding because they have particular nutritional needs and because their nutritional status impacts that of infants, and as women in the Bangladeshi camps generally become mothers early, adolescent girls receive supplementary feeding to prevent babies from being born underweight. ${ }^{49}$

In addition to supplementary and therapeutic feeding programmes, efforts to address child malnutrition largely take the form of programs that target mothers and seek to improve their ability to care for their children. In interviews, most humanitarian workers locate the causes of child malnutrition within refugee families - a result of "poor care practices". Indeed, as one NGO employee explains, "[i]f children are malnourished there is something lacking at the family level". ${ }^{50}$ This explanation is reiterated in a joint WFP-UNHCR assessment report with a focus on nutrition in the Bangladeshi camps. While causes such as food sharing with unregistered refugees and lack of opportunities to earn an income are mentioned in passing, the report emphasizes the importance of factors within the family: "Though the causes of malnutrition are very complex to identify, it is foreseen that child care and feeding practices play a significant role along with social issues which makes the mother unable to address child nutrition". ${ }^{51}$ The "social issues" mentioned here refer to a discussion in the report of the perceived lack of participation and engagement in camp life among the refugees, who are described as suffering from a dependency mindset resulting from the long-term provision of aid to the camps. The report therefore emphasizes the need for community mobilization to address malnutrition. Notably, a "particular focus on women allowing them to appreciate what it means to be empowered", is recommended. ${ }^{52}$ As one UN employee relates, the lack of community

\footnotetext{
${ }^{47}$ UNHCR, UNHCR Bangladesh Fact Sheet, 2013.

${ }^{48}$ WFP \& UNHCR, Report, 2010.

${ }^{49}$ Interview 30, NGO Bangladesh; Interview 35, UN Agency Bangladesh, Cox's Bazar 7 Mar. 2011.

${ }^{50}$ Interview 30, NGO Bangladesh.

${ }^{51}$ WFP \& UNHCR, Report, 2010, 17

${ }^{52}$ WFP \& UNHCR, Report, 2010, 6
} 
engagement and the dependency mentality of the refugees is also seen as negatively impacting their ability to take care of their children:

One of the weakest areas that this community needs to really enhance is good parenting skills. We have seen that a lot more children are at risk in the camps largely because they are facing problems, eh, because their parents have neglected them or the parents just have no capacity to take care of them. ${ }^{53}$

While this interviewee speaks of parents, others more explicitly speak of mothers' failures to properly feed and care for their children:

Malnutrition can be linked to care practices. Most of the times this is a mother taking care of the children. One important point in terms of malnutrition in the camps is that children from six to twenty-four months are the most affected by malnutrition. This is a time when the woman stops exclusive breastfeeding and should introduce food, so this is a very important role for the mother'. ${ }^{54}$

Consequently, to address child malnutrition it is seen as critical to engage mothers and educate them to be better able to actively prevent their children from becoming malnourished. This is done through interventions such as cooking demonstrations and nutrition education, health and hygiene promotion sessions, breastfeeding counseling, kitchen gardening programmes, and group counseling for mothers. ${ }^{55}$ Women are recruited to many of these interventions when they bring their children to the malnutrition center. Agencies working with malnutrition clearly state that they target women because they are assumed to be responsible for the care of children. When asked about the organization's approach to gender equality, an NGO worker explains that "[n]inety per cent of our beneficiaries are women: mothers, caregivers". However, the reason that women are targeted is not to promote gender equality or women's empowerment. The interviewee makes it clear that their focus is not gender issues but nutrition, and as mothers are the main caretakers of children, "naturally most beneficiaries are women". 56

\footnotetext{
${ }^{53}$ Interview 46, UN agency Bangladesh, Dhaka 15 Mar. 2011.

${ }^{54}$ Interview 47, NGO Bangladesh, Dhaka 16 Mar. 2011.

${ }^{55}$ Interview 30, NGO Bangladesh; Interview 31, NGO Bangladesh, Cox’s Bazar 3 Mar. 2011; Interview 47, NGO Bangladesh.

${ }^{56}$ Interview 30, NGO Bangladesh.
} 
Women are represented as mothers and caregivers, and in this capacity they are seen as crucial actors in addressing child malnutrition. However, the way women perform their reproductive responsibilities is also problematized and constructed as an area where humanitarian interventions are needed. As an NGO worker explains, when women come with their children to the malnutrition center, "what we do is try to assess every woman, the different skills she has regarding care practices and lifestyle". ${ }^{57}$ Based on this assessment, women are recruited into focus groups where they are counseled on issues such as breastfeeding, child development, and hygiene. Educating mothers and teaching them more "modern" ways of caring for their children is seen as an important strategy against child malnutrition, and the role of group counseling is described as promoting "new knowledge against traditional knowledge". ${ }^{58}$ For example, humanitarian agencies promote exclusive breastfeeding during a child's first six months, but describe traditional practices of giving honey water to children to give them a sweet character as an obstacle to their efforts. In the conditions of the camps, access to clean water is limited and there is a risk that dirty honey water will contribute to diarrhea and malnutrition. ${ }^{59}$ Through group counseling, humanitarian agencies seek to "reinforce the link between the mother and the child" and enhance mothers' sense of care and responsibility for their children. ${ }^{60}$ This is seen as important in the context of the perceived refugee dependency, passivity and resulting neglect of children discussed above. For refugee women, active community participation and active mothering are represented as closely intertwined. A UN employee who comments on the effects of successful efforts to mobilize and activate the refugee community relates that now, "[y]ou see a lot more women participating, a lot more women investing in their children, a lot more women contributing to the community". ${ }^{61}$

In group counseling sessions, the topic of domestic violence is also discussed. However, the purpose of discussing domestic violence in this forum is not primarily to provide support or assistance to women who are subjected to violence. The aim is to provide a platform where women can share experiences and discuss how they can handle instances of violence and manage their relationships with their husbands better. Women are encouraged to consider whether there may be a reason why husbands become angry, and to develop their conflict resolution skills. In the words of an NGO worker involved in group counseling, a "beating is

\footnotetext{
${ }^{57}$ Interview 31, NGO Bangladesh.

${ }^{58}$ Interview 31, NGO Bangladesh.

${ }^{59}$ Interview 47, NGO Bangladesh.

${ }^{60}$ Interview 47, NGO Bangladesh.

${ }^{61}$ Interview 46, UN agency Bangladesh.
} 
not a fact without explanation". ${ }^{62}$ The reason that the topic of domestic violence and conflict resolution is discussed in focus groups is that family conflict is seen to impact women's ability to care for their children negatively: "if the mother is not in a well-minded state she is not free to take care of the child". 63

The approach to domestic violence in group counseling sessions is illustrative of the opportunities and limitations of programmes where women's participation is promoted for the purpose of addressing child malnutrition in the Bangladeshi refugee camps. As several interviewees point out, the mere fact that women are given a reason to meet outside of their homes with no men present provides rare opportunities to share experiences and discuss common problems. ${ }^{64}$ Nutritional programs thereby create legitimate social spaces for women, which may well have transformative potential despite this not being the objective of the programs. Furthermore, programs seeking to engage women in kitchen gardening or include them in educational sessions makes women visible and represents them as important actors in a context where any public role for women is often denied. However, as the approach to domestic violence in focus groups exemplify, there is no conscious effort to alter unequal relations of power or change women's subordinated status. Despite the fact that many interviewees describe Rohingya women as extremely vulnerable, oppressed and largely confined to the home, nutritional programmes tend to reify existing gender relations rather than to question them. In interviewees' descriptions of nutritional programs, a representation of women as primary caretakers of children is as much a normative prescription as an empirical observation. Women are not only targeted because they are assumed to already be responsible for childcare, but nutritional programs give a clear message that it is the responsibility of mothers to care for their children, and to learn to do it better.

This construction of women's participation as a resource against child malnutrition is not only problematic because it reifies unequal gender relations, but also because it makes refugee women with extremely limited access to resources and space of maneuver responsible for solving a very complex problem. When efforts to address malnutrition focus solely on feeding programs and on engaging mothers in improving their childcare practices, other factors contributing to malnutrition are obscured. In particular, structural factors that partly originate beyond the camp context have a great impact on food security and nutrition in the camps. This

\footnotetext{
${ }^{62}$ Interview 31, NGO Bangladesh.

${ }^{63}$ Interview 31, NGO Bangladesh.

${ }^{64}$ Interview 31, NGO Bangladesh; Interview 47, NGO Bangladesh; Interview 35, UN agency Bangladesh.
} 
is pointedly expressed by a UN employee frustrated with the, in her view, misguided focus on community mobilization as a solution to malnutrition:

There are things that are beyond the refugees' control, beyond UNHCR's and WFP's control, that affects food security. And let's not have any illusions that somehow, if we mobilize the community and empower all the women that somehow there will be less children in the malnutrition center. They are there because there are five thousand people in the camps who do not get food. Therefore food is being shared. There are constant breaks in the pipeline and the supply of fuel, which means people sell food in order to buy fuel to cook the remaining food. And there is not enough food diversity in the camps, because people do not have access to land, they cannot grow fruit and vegetables, and they have very limited access to work so they cannot get cash to supplement the dry rations that they get. And these are the reasons; these are the main reasons why there is malnutrition and poor food security status in the camps. And community mobilization is not going to impact on those things at all. ${ }^{65}$

In the view of this humanitarian worker, community mobilization, including the promotion of women's participation, constitutes a diversion that prevents action to address these structural causes of malnutrition: "I hate the way people throw in words like community mobilization and empowering women, because it does not mean anything until you say what you think we should actually do". 66

The construction of child malnutrition as a problem originating in the "poor care practices" of refugee families, particularly mothers, reflects a governmental impulse to render problems intelligible, manageable and amenable to practical solutions within the framework of humanitarian aid practices. ${ }^{67}$ The structural causes of malnutrition and other problems facing refugees are, as the interviewee quoted above points out, often rooted in geopolitical relations and host government policies beyond the control of humanitarian actors. Thinking about their limited ability to change the situation of refugees frequently makes humanitarian "feel that we are a Band-Aid, when you require major surgery". 68 Consequently, in humanitarian programming child malnutrition is conceptualized and approached as a problem that can be

\footnotetext{
${ }^{65}$ Interview 34, UN agency Bangladesh, Cox’s Bazar 7 Mar. 2011.

${ }^{66}$ Interview 34, UN agency Bangladesh.

${ }^{67}$ N. Soguk, States and strangers: Refugees and displacements of statecraft, Minneapolis:Univiversity of Minnesota Press, 1999, 50

${ }^{68}$ Interview 46, UN agency Bangladesh.
} 
solved through interventions that educate and convince mothers to apply the right practices and techniques in the daily care for their children. This approach reflects an unrealistic belief in the ability of poor and resource-constrained households to adapt and survive despite the severity of the structural conditions surrounding them, what González de la Rocha has termed a "myth of survival" rooted in neoliberal development economics. ${ }^{69}$ Women's participation is not only instrumentalized, but expected to deliver unrealistic results. As Madhok and Rai argues, neoliberal formulations of agency individualizes responsibility but fails to recognize the systemic power relations and the structural constraints within which agential subjects seek to act. ${ }^{70}$ Promoting women's participation while failing to addess overall power relations "leaves women with new roles to fulfil but no institutional leverage to fulfil them effectively", as ElBushra pointedly argues. ${ }^{71}$

Further, programs that seek to address child malnutrition through engaging, activating and educating mothers make existing gender relations a vehicle for the implementation of humanitarian programs and goals. This approach actively makes use of a gender analysis to design effective programs, but does not question the relations of power constitutive of gender roles and divisions of labor. In doing so women's position in the domestic sphere, responsible for childcare and household work, is affirmed but also reconstituted in accordance with humanitarian "best practices". While gender provides an important "grid of intelligibility" humanitarians working on nutrition in the camps, gender is not politicized as a relation of power. In the words of Hyndman and de Alwis, targeting women in humanitarian programs in and of itself "is a gendered practice, but not a feminist one". ${ }^{73}$

\section{Thailand: women as resources for efficient distribution of food}

Next, a background to the refugee situation along the Thai-Burma border is provided, and the current camp context where humanitarian aid programs are implemented is briefly described. This is followed by the analysis of how women's participation is represented and employed as a means to improve the efficiency and quality of food distribution in the camps.

\footnotetext{
${ }^{69}$ M. González de la Rocha, "The Construction of the Myth of Survival", Development and Change 38(1), 2007, 45-66.

${ }^{70}$ Madhok \& Rai. "Agency, Injury, and Transgressive Politics", 2012.

${ }^{71}$ El-Bushra. "Gender and forced migration", 2000.

${ }^{72}$ J. Hyndman \& M. de Alwis, "Reconstituting the Subject: Feminist Politics of Humanitarian Assistance" in M. Hajdukowski-Ahmed, K. Nazilla and H. Moussa (eds.) Not Born a Refugee Woman: Contesting Identities, Rethinking Practices, New York \& Oxford:Berghahn Books, 2008, 89.

${ }^{73}$ Ibid, 93.
} 


\subsection{Burmese refugees in Thailand}

The situation of Burmese refugees in Thailand constitutes one of the most protracted displacement situations in the world. ${ }^{74}$ The first refugee camps on the Thai side of the ThaiBurmese border were established in 1984 when Karen refugees fled across the border following advances in the counterinsurgency campaign of the Burmese military against the Karen National Union (KNU). ${ }^{75}$ The KNU was formed in 1947 to fight for an independent Karen nation, and has since been engaged in armed struggle against the government. Pervasive human rights abuses committed as part of the government's counterinsurgency campaign have forced people in the border regions of Eastern Burma to live in constant fear, displacing many people several times during 60 years of war. ${ }^{76}$ Throughout the first decade after their establishment, the refugee camps in Thailand were relatively self-reliant as refugees could grow crops across the border, complemented by only minimal assistance by international NGOs already present in Thailand. Refugees organized and governed the camps modeled after the villages they left behind, and the Thai government accepted their "temporary" presence without much interference. ${ }^{77}$ When the first NGOs arrived, they were impressed by what they found to be well-organized Karen communities, and took an approach of working in partnership with the refugee governance structures. ${ }^{78}$ With the gradual loss of territory controlled by the KNU and other minority forces, the stream of refugees into Thailand intensified in the 1990's and the size of the refugee camps increased. In addition, between 1995 and 1998, 12 refugee camps were attacked and burnt by the Burmese military in cross-border operations. These changes resulted in a shift in Thai policy. The camps were consolidated into fewer, larger camps to be able to guarantee security and control the movements of the refugees, who were no longer allowed to travel or work outside of the camps. The UNHCR was also invited to provide protection and monitoring, and the international humanitarian presence in the camps increased significantly. ${ }^{79}$

Currently there are 130,000 refugees in nine camps along the border. However, only about 80,000 are officially registered as such, as registration has not been carried out after 2005 . The majority of the refugees are Karen, but there are also refugees from minority groups such

\footnotetext{
${ }^{74}$ UNHCR UNHCR Country Operations Profile 2013 - Thailand, 2013, available at http://www.unhcr.org/cgibin/texis/vtx/page?page=49e489646\&submit=GO (last visited 14 Nov. 2013).

${ }^{75}$ H. Lang, Fear and Sanctuary. Burmese Refugees in Thailand, New York:Cornell Southeast Asia Program, 2002.

${ }^{76}$ A. South, Ethnic Politics in Burma: States of Conflict., London \& New York:Routledge, 2008.

${ }^{77}$ S. Thompson, "Community-based Camp Management." Forced Migration Review 30 (Burma's Displaced Peoples), 2008.

${ }^{78}$ Thai Burma Border Consortium (TBBC), Between Worlds: Twenty Years on the Border, 2004, available at http://theborderconsortium.org/resources/resources.htm (last visited 8 Jan. 2013), 19

${ }^{79}$ Lang, Fear and Sanctuary, 2002; Thompson, "Community-based Camp Management", 2008.
} 
as Karenni, Shan, and Mon, as well as some Burman refugees. ${ }^{80}$ Links between the refugee populations and the Karen armed insurgency in Burma have remained strong, and the camps have provided important bases for Karen nationalism and various forms of political activism. ${ }^{81}$ The UNHCR did not begin operations on the Thai-Burmese border until 1998, and NGOs are still the main humanitarian actors although the UNHCR has been expanding its role on the border in recent years. Humanitarian aid and services are mainly provided by a network of about 15 national and international NGOs. Further, aid and services are coordinated and partly implemented by the refugees themselves through a system for community-based camp management. The camps are governed by elected refugee committees; the Karen Refugee Committee (KRC) in seven camps and the Karenni Refugee Committee (KnRC) in the two northernmost camps. A Camp Committee (CC) is responsible for the day to day running of each camp and coordinates services such as education, health, and justice. ${ }^{82}$ Since 2005 a large-scale resettlement programme has been ongoing, and to date more than 80,000 refugees have left the camps to be resettled in a Western country. However, people have continued to seek safety in the camps, so the total camp population has not decreased significantly. Recently, developments in Burma have raised hopes that political reforms and the still fragile peace in Eastern Burma may eventually create conditions where repatriation is possible. ${ }^{83}$

\subsection{Food distribution and women's participation in the Thai refugee camps}

Since the mid-1990s refugees in the camps along the Thai-Burma border have not been allowed to travel or work outside of the camps. This policy, and the ongoing armed conflict across the border, has reduced refugees' opportunities to earn an income to buy food or access land where they can grow crops. Consequently, most refugees are reliant on food rations provided by humanitarian organizations in order to survive. An international NGO is in charge of supplying food and other items such as cooking utensils and building materials to the camps, but warehousing and distribution of food and other supplies is largely administered by the refugee camp committees. Refugee staff working with distribution receives a small salary, or stipend.

\footnotetext{
${ }^{80}$ The Border Consortium (TBC), Refugee and IDP Camp Populations: September 2013, 2013, available at http://theborderconsortium.org/camps/2013-09-sep-map-tbc-unhcr.pdf (last visited 14 Nov. 2013). "Burman" denotes refugees from the Burmese ethnic majority, while "Burmese" denotes all refugees from Burma.

${ }^{81}$ A. South, "Karen Nationalist Communities: The 'Problem' of Diversity", Contemporary Southeast Asia: A Journal of International and Strategic Affairs 29(1), 2007, 55-76: 62-63

${ }^{82}$ S. Banki \& H. Lang, "Protracted Displacement on the Thai-Burmese Border: the Interrelated Search for Durable Solutions" in H. Adelman (ed.) Protracted displacement in Asia: no place to call home.

Aldershot:Ashgate Publishing, 2008, 59-82.

${ }^{83}$ UNHCR, UNHCR Country Operations Profile, 2013.
} 
In interviews, many humanitarians point out that due to the crucial importance of food rations in refugee camp life, the control and distribution of food is a position of power that can potentially be abused. For example, there are allegations that withdrawal of food rations has been used as sanctions against opponents to the camp leadership, ${ }^{84}$ and food aid has functioned as an important support base for the military campaign of the KNU across the border. ${ }^{85}$ In addition, selection procedures for jobs in food distribution have previously been less than transparent, with jobs being allocated to friends of the camp committees. ${ }^{86}$ Therefore, in 2006 the responsible NGO, The Border Consortium (TBC, previously the Thailand Burma Border Consortium, TBBC), took steps to strengthen capacity and transparency and improve monitoring of the management and distribution of food and other supplies in the camps. Increasing women's participation in food distribution was considered an important aspect of this endeavor. ${ }^{87}$ Larger and more diverse camps had put the existing distribution staff under increasing pressure, and donor requirements increasingly emphasizing accountability and efficiency further contributed to increase their workload. ${ }^{88}$ Thus, TBC chose to increase women's participation through opening up a significant number of new positions in food management and distribution, thereby also increasing the total number of staff. In cooperation with the camp committees, the entire distribution process was broken down to identify where additional staff was needed, and what their responsibilities would be. This process challenged perceptions that distribution was mainly about moving around heavy supplies, and therefore a man's job, and showed that many areas in need of strengthening were in fact administrative. As a result, 96 new positions were opened up that only women could apply for. These positions included stock taking, stock recording, updating ration books, and weighting rations at distribution. Consequently, during the second half of 2006 the number of women in food distribution increased from 11 per cent to 35 per cent. ${ }^{89}$ During the following years, TBC continued to consciously increase the number of women in food distribution through ensuring that positions that become vacant due to departures for resettlement were made available to women. In early 2008, women made up 41 per cent of distribution staff. ${ }^{90}$

\footnotetext{
${ }^{84}$ Interview 28, Telephone interview UN agency Thailand, 24 Feb. 2011.

${ }^{85}$ South, Ethnic Politics in Burma, 2008, 95

86 TBBC, TBBC Programme Report January to June 2006, 2006, available at http://theborderconsortium.org/resources/2006-6-mth-rpt-jan-jun.pdf (last visited 20 Nov. 2013), 20

${ }^{87}$ TBBC, TBBC Programme Report January to June 2006, 2006, 20

${ }^{88}$ Interview 14, NGO Thailand, Mae Sot 29 Oct. 2010.

89 TBBC, TBBC Programme Report January to June 2006, 2006, 20; TBBC, TBBC Programme Report July to December 2006, 2006, available at http://theborderconsortium.org/resources/2006-6-mth-rpt-jul-dec.pdf (last visited 20 Nov. 2013), 21

90 TBBC, TBBC Programme Report July to December 2007, 2007, available at http://theborderconsortium.org/resources/2007-6-mth-rpt-jul-dec.pdf (last visited 20 Nov. 2013), 33; TBBC,
} 
In this case, increasing women's participation was chosen as a central strategy to address deficits in the capacity and transparency of food distribution. As an interviewee explains, women's participation was expected to improve food distribution because of the particular qualities they were assumed to possess. Women are described as more cooperative, less hierarchical, and taking a more orderly approach to their work in distribution. Further,

I think it is accepted as a fact that when women are involved in the distribution of food it is generally more effective, it is more cost effective, and there is less wastage, there is more accurate distribution, there is more transparency and there is sort of better, yeah, just more efficiency in the distribution of food... and that has been lacking. ${ }^{91}$

For these reasons, increasing women's participation is described as "important not just for...not just to wave a flag of women's involvement, but for practical, for real, practical reasons in terms of food distribution efficiency as well". ${ }^{92}$ Further, as an NGO worker relates, women's control over food resources is assumed to ensure that they are used for household consumption, while men are assumed to be less reliable:

I think research has shown that if it [the food ration] is given to the women, it is distributed more equally amongst the household. If it is given to the male, sometimes it might be allocated a little bit, but used for their own kind of purposes. ${ }^{93}$

Notably, men are described as frequently selling food rations to buy alcohol, while women are thought to use them to feed their children. ${ }^{94}$ Thus, having women involved in the distribution of food as well as delivering the food ration into women's hands is represented as vital to combat corruption and misuse of food aid. Ensuring women's equal participation therefore facilitates the work of humanitarian organizations:

\footnotetext{
TBBC Programme Report January to June, 2008, available at http://theborderconsortium.org/resources/2008-6mth-rpt-jan-jun.pdf (last visited 20 Nov. 2013), 27

${ }^{91}$ Interview 14, NGO Thailand.

${ }^{92}$ Interview 14, NGO Thailand.

${ }^{93}$ Interview 16, NGO Thailand, Mae Sot 1 Nov. 2010.

${ }^{94}$ Interview 3, NGO Thailand, Mae Sot 28 Apr. 2010.
} 
I honestly believe it makes for more effective programming...female distributors of food and medical aid ensures that there is less corruption, less abuse in the distribution of those services, food and medical aid. And that makes organizations' work easier. ${ }^{95}$

Further, women's participation in distribution is also represented as a remedy against sexual abuse and exploitation, a salient issue in humanitarian aid work at the time of the interviews. In Thailand, work was ongoing to establish codes of conduct and reporting mechanisms that would deter refugee staff as well as humanitarian employees from sexually abusing beneficiaries of aid. In the context of food distribution, women's participation is described as critical to

avoid the abuses, the corruption that comes when men do it [distribute humanitarian aid], who are exchanging food for sex or trying to abuse their positions of power, then the government start learning about it, then the contributing taxpayers learn that they are funding this kind of nonsense, and then it makes trouble for everyone. So that is why I think it is more effective when you have gender balance in the operations. ${ }^{96}$

In recent efforts to increase the participation of women in food distribution in the Thai refugee camps, instrumental arguments for women's inclusion have been at the forefront. Women are to be included because they are expected to act in particular ways and contribute with qualities that has previously been lacking. Women's participation in food distribution is therefore expected to improve efficiency and reduce corruption and abuse. As feminist scholars have argued, when women are included as means to other ends, there is a risk that their inclusion will no longer be seen as relevant once it is not strategically necessary. In addition, if women do not act as they are expected, how can their participation then be motivated? For instance, reifying stereotypes of women as cooperative and family-oriented can limit women's opportunities to act in other ways - for example pursuing political leadership or choosing not to have children. ${ }^{97}$ Additionally, rather than being an issue of justice or power, women's participation in food distribution is represented as "best practice" - simply the right way of implementing effective programs. As an NGO worker remarks, "if you believe in best practice, then you can see the value of having, you know, both genders involved". ${ }^{98}$ This conception is

\footnotetext{
${ }^{95}$ Interview 12, NGO Thailand, Mae Sot 26 Oct. 2010.

${ }^{96}$ Interview 12, NGO Thailand.

${ }^{97}$ Cohn \& Enloe. "A conversation", 2003; Goetz, "Political Cleaners", 2007; Cohn, "Mainstreaming Gender", 2008.

${ }^{98}$ Interview 25, NGO Thailand, Mae Sot 19 Nov. 2010.
} 
consistent with a neo-liberal rationality that de-politicizes gender, emphasizing the "business case" for gender equality but preventing attention to the power relations that are (re)produced by humanitarian gender programs.

Nevertheless, despite the instrumental motivations for increasing women's participation in food distribution, the process did challenge existing conceptions of what women's roles in the camps could be. While stereotypical assumptions about women's qualities and behavior were used to motivate their inclusion, it did nonetheless give women access to spaces from which they had previously been excluded. In addition, efforts to increase women's participation and strengthen food distribution were one part of a broader project aimed at strengthening and supporting the refugee-led camp management structures, the Camp Management Project (CMP). Within this project, started in 2004, humanitarian organizations in cooperation with camp committees worked to increase the number of women in leadership positions, for example in camp committees and section committees. ${ }^{99}$ Arguments focusing on women's specific contribution and capacities were prevalent not only in relation to food distribution, but also in relation to camp leadership and decision-making. As a CBO representative comments,

The participation of women in decision-making is important to make good decisions. Women are better than men in some areas, and the experience of women is different. For example women know more details and can contribute to planning and give advice. ${ }^{100}$

Despite its possible limitations, a representation of women as resources in this case legitimated processes that in effect contributed to question and destabilize previous gender relations. Indeed, as an NGO employee relates, the process of going through the different responsibilities in distribution and camp management contributed to make gendered expectations visible and thereby open them up to discussion:

We had to begin very basic and break down all jobs and let the camp committees define jobs, that has been a lot of it. Then anyone can see what is expected, and that a woman might as well do the job, instead of it being considered somehow stepping into a male domain in an undefined way. When we started, we asked the women's organizations if

\footnotetext{
99 TBBC, TBBC Programme Report January to June 2006, 2006, 20; TBBC, TBBC Programme Report July to December 2006, 2006, 20-21

${ }^{100}$ Interview 19, CBO Thailand, Mae La refugee camp 4 Nov. 2010.
} 
they wanted to be involved in camp management or if they rather do something else. And they said that they wanted to be involved and they wanted to have a voice, but they wanted us to help them and work with the men, because the issue was sensitive. The men just thought of women as people taking care of the house, and needed to open their eyes to what they can do and the capacities they bring to the table. ${ }^{101}$

Yet, the narrative of this NGO worker remains within the discourse of women as resources, emphasizing that change comes from convincing men that women have particular capacities to bring to the table. However, refugee women's organizations in the camps has been a key driving force behind changes towards increased participation of women in camp leadership and other public roles, and has challenged the perspective on women's participation as resource by representing it as an issue of equality, rights and justice. Thereby the presence of organized refugee women has contributed to re-politicizing women's participation and trouble a representation of women's participation as simply "best practice" for effective humanitarian programming. From the perspective of refugee women's organizations, women's participation is not a management strategy for effective and efficient humanitarian programming; rather, it is about women's right to be present and have a voice "at every decision-making level, in leadership, in conflict resolution, in peacemaking". ${ }^{102}$ Women's participation is represented by refugee women as the most essential strategy to ensure "[t]hat women can do all things that men can" and acheive gender equality. ${ }^{103}$ Women's increased participation in camp management over the past decade is seen as an important step in this direction:

[I]f we look back, women did not have decision-making positions. Very few. So if we compare the past and now, there is a big change in women's leadership roles. In the past there were no women in the camp committee, now women participate. ${ }^{104}$

Moreover, donor requirements and humanitarian programs have strengthened the position of women's organizations in the refugee camp communities, and programs such as the CMP has contributed to open up new opportunities for women. Stressing the combined effect of refugee women's struggle and the actions of donors and humanitarian organizations, a representative

\footnotetext{
${ }^{101}$ Interview 9, NGO Thailand, Bangkok 10 May 2010.

102 Interview 15, CBO Thailand, Mae Sot 1 Nov. 2010.

${ }^{103}$ Interview 20, CBO Thailand, Mae La 4 November 2010.

${ }^{104}$ Interview 20, CBO Thailand.
} 
for a women's organization comments a question on whether there is gender equality in the refugee camps today in the following way:

Not really. But compared to in the start there has been a lot of change. Before there were no women in camp committees, no women security guards, no head teachers. The change is not only a result of our struggle, but also due to donor requirements, international requirements are also important. So change takes not only the struggle of women here but other people have to contribute, and also men. ${ }^{105}$

Further, refugee women explain that pressure from donors and humanitarian organizations to increase women's participation in the camps, regardless of whether it has been driven by instrumental motives, has enabled them to back their work with the legitimacy provided by international norms and policies. This has made it possible for refugee women activists to more explicitly advocate for women's rights and equality within their communities. ${ }^{106}$ Interestingly, refugee women's organizations have been able to draw on an international humanitarian discourse that encourages women's participation due to its envisioned utility for other goals to strengthen their position and create a discursive space from where to challenge this instrumental perspective on women's participation and further their own struggle.

Thus, while instrumental arguments for women's participation has been quite pronounced in humanitarian programs in the Thai refugee camps, they have nonetheless been used to legitimate women's inclusion in new spaces and new roles, thereby contributing to increase women's opportunities and influence in the camps, destabilizing and modifying gendered relations of power. However, instrumental arguments have also been complemented by a perspective put forward by refugee women, emphasizing women's rights to have a voice in their communities and be equally represented in positions of power.

\section{Conclusion}

Women's participation in the implementation of humanitarian aid programmes is today frequently expected to deliver a range of good results. However, while the utility of women's participation as a means to a variety of humanitarian goals is emphasized, the question of whether current participatory practices actually improve refugee women's lives or contribute to greater gender equality receives far less attention. This analysis has aimed to show how

\footnotetext{
${ }^{105}$ Interview 15, CBO Thailand.

${ }^{106}$ Interview 15, CBO Thailand
} 
women's participation is represented and employed as a means to improve the effectiveness and efficiency of humanitarian aid, and examine how such strategies affect the gendered relations of power that shape women's lives in the camps. Further, it has argued that the construction of women's participation as a resource for humanitarian aid effectiveness rather than an aspect of realizing gender equality must be understood as an expression of the current dominance of neo-liberal governmentalities in the field of humanitarian aid.

In Bangladesh as well as in Thailand, a "business case" for women's participation clearly motivates its promotion. Women's participation is represented not as an issue of equality, justice or access to decision-making power but as "best practice" for the design and implementation of effective humanitarian aid programs. Through a variety of technologies of agency, women are called to embody particular subjectivities and participate actively in ways that makes them useful for the effective achievement of humanitarian goals such as public health or efficient distribution of food. In Bangladesh, humanitarian agencies working to address child malnutrition represent "community mobilization" as the key to prevent malnutrition. In particular, mothers' abilities to feed and care for their children properly are questioned, and mothers are targeted by a variety of programs that seek to activate, educate and counsel them to make them better, more engaged mothers and caretakers. The way in which mothers perform their reproductive responsibilities is constructed both as a cause of malnutrition and as its potential remedy. The issue of child malnutrition is thus constructed as closely intertwined with the psychological state and the behavior of mothers. To convince women, in their capacities as mothers and caretakers, to participate in the right way is therefore seen as crucial to address child malnutrition. In Thailand, increasing women's participation has been a central strategy in efforts to improve the capacity, transparency and efficiency of food distribution in the refugee camps. Through different forms of targeted recruiting of women distribution staff, women's representation was significantly increased over the course of a few years. These efforts were informed by assumptions that women are less corrupt and more family-oriented, reliable, orderly and cooperative than men. Therefore, increasing women's participation was expected to reduce corruption, misuse and wastage of food, ensure that food was used for household consumption, and prevent sexual abuse related to food distribution.

However, while programmes in both contexts are informed by similar neo-liberal rationalities where women's participation is represented as a resource for the achievement of other goals, their effects are nonetheless different. In Bangladesh, efforts to address child malnutrition through reforming mothers' "care practices" reify women's subordination and their confinement to the domestic sphere. In addition, refugee mothers are made responsible for 
a complex structural problem that lies far beyond their control. In a context where agency and access to resources is severely restricted this is a heavy burden to shoulder. This approach is blind to gendered relations of power as well as structural injustices, and pointedly illustrates the limitations of a de-politicized and instrumental conception of women's participation as a resource for humanitarian aid effectiveness.

In contrast, in Thailand essentialist images of women have been paradoxically employed to legitimate women's inclusion in previously male spheres. The specific qualities women are assumed to contribute with are closely linked to their roles as mothers - women are represented as family-oriented, selfless, and caring, and their participation in distribution is therefore expected to ensure that food reaches the mouths of families. Further, by virtue of their womenspecific qualities, perspectives and experiences women are represented as able to improve the quality of camp leadership and decision-making. Interestingly, a neo-liberal discourse of women-as-resources in this case contributed to open up space to challenge and destabilize, and thereby to politicize, gendered relations of power even though this was not the primary objective. One important explanation for this is the role of refugee women activists, who have benefitted from the instrumental legitimation of women's participation and leadership but also challenged the neoliberal "business case" perspective on women's participation through a focus on equality, justice and rights. Thus, this case illustrates the perpetually unfinished and contradictory nature of dominant rationalities. The potential for resistance and reproblematization is always inherent in any governing project, and the relations of power it produces can be modified and destabilized from within. ${ }^{107}$ Indeed, as Fraser emphasizes, no vocabulary is inherently oppressive or emancipatory; all can be employed in different, sometimes unexpected, ways. ${ }^{108}$

However, although programmes that employ women's participation as a means to humanitarian aid effectiveness may sometimes also contribute to improve women's position and change unequal gender relations, the treatment of equality as a side effect, not a goal in its own right, is nonetheless a source of concern. As we have seen, such an approach to gender and to women's participation enables the use of humanitarian aid resources to support and reinforce women's marginalization and inequality if it contributes to effectively achieve goals related to public health and nutrition. Indeed, gender as an instrument for humanitarian analysis and planning has become so disconnected from its feminist origins that it can now be used in ways

\footnotetext{
${ }^{107}$ M. Foucault, The History of Sexuality, vol. 1, An Introduction, New York:Vintage Books, 1978, 95-96 ${ }^{108}$ N. Fraser, Unruly practices: Power, discourse, and gender in contemporary social theory, Minneapolis:Univ of Minnesota Press, 1989, 63
} 
that are ignorant of, or even supportive of, the relations of power that the concept of gender was intended to expose and to change. As Edwards and Hyndman and de Alwis have respectively argued, renewed engagement with the political project of feminism is sorely needed to counter the current de-politization and instrumentalization of gender in humanitarian aid; salvage its potential as an analytical lens that draws attention to structures of power, inequality, privilege and disadvantage; and bring the goals of equality and justice back in. ${ }^{109}$

${ }^{109}$ Edwards, "Transitioning Gender", 2010; Hyndman \& de Alwis, "Recontituting the Subject", 2008. 


\section{List of References}

Banki, S. \& H. Lang, "Protracted Displacement on the Thai-Burmese Border: The Interrelated Search for Durable Solutions" in H. Adelman (ed.) Protracted displacement in Asia: no place to call home, Aldershot:Ashgate Publishing, 2008, 59-82

Barnett, M., "Humanitarianism Transformed." Perspectives on politics 3(4), 2005, 723-740

Barnett, M. \& M. Finnemore, "Defining Refugees and Voluntary Repatriation at UNHCR" in M. N. Barnett and M. Finnemore (eds.), Rules for the world: International organizations in global politics, Ithaca \& London:Cornell University Press, 2004, 73-120

Bessis, S., "International Organizations and Gender: New Paradigms and Old Habits", Signs 29(2), 2004, 633-647

Bjarnegård, E. and E. Melander, "Revisiting Representation: Communism, Women in Politics, and the Decline of Armed Conflict in East Asia", International Interactions 39(4), 2013, 558-574

Brown, W., Edgework: Critical essays on knowledge and politics, Princeton:Princeton University Press, 2009

Burchell, G., C. Gordon \& P. Miller, The Foucault effect: studies in governmentality: with two lectures by and an interview with Michel Foucault, London:Harvester Wheatsheaf, 1991.

Buscher, D., "Refugee Women: Twenty Years On”, Refugee Survey Quarterly, 29(2), 2010, 4-20

Cohn, C., "Mainstreaming Gender in UN Security Policy: A Path to Political Transformation?" in S. Rai \& W. Georgina (eds.), Global Governance: Feminist Perspectives. New York:Palgrave Macmillan, 2008

Cohn, C. and C. Enloe, "A conversation with Cynthia Enloe: Feminists look at masculinity and the men who wage war", Signs 28(4), 2003, 1187-1107

Cornwall, A., E. Harrison, A. Whitehead, "Gender Myths and Feminist Fables: The Struggle for Interpretive Power in Gender and Development", Development and Change 38(1), 2007, 1-20

Dean, M., Governmentality: power and rule in modern society, London:Sage Publications, 2010

Dillon, M. \& J. Reid, "Global governance, liberal peace, and complex emergency", Alternatives: Global, Local, Political 25(1), 2000, 117-143

Edwards, A., "Transitioning Gender: Feminist Engagement with International Refugee Law and Policy 1950-2010”, Refugee Survey Quarterly, 29(2), 2010, 21-45

El-Bushra, J., "Feminism, Gender, and Women's Peace Activism." Development and Change 38(1), 2007, 131-147

El-Bushra, J., "Gender and forced migration: editorial", Forced Migration Review 9 (Gender and Displacement), 2000

Fiddian-Qasmiyeh, E., "'Ideal' Refugee Women and Gender Equality Mainstreaming in the Sahrawi Refugee Camps: 'Good Practice' for Whom?”, Refugee Survey Quarterly, 29(2), 64-84

Foucault, M., The History of Sexuality, vol. 1, An Introduction, New York:Vintage Books, 1978

Foucault, M., "Governmentality" in. G. Burchell, C. Gordon and P. Miller (eds.) The Foucault effect: studies in governmentality: with two lectures by and an interview with Michel Foucault. London:Harvester Wheatsheaf, 1991, 87-104

Fraser, N., Unruly practices: Power, discourse, and gender in contemporary social theory, Minneapolis:University of Minnesota Press, 1989

Goetz, A.M., "Political Cleaners: Women as the New Anti-Corruption Force?", Development and Change 38(1), 2007, 87-105 
González de la Rocha, M., "The Construction of the Myth of Survival", Development and Change 38(1), 2007, 45-66

Helms, E., "Women as agents of ethnic reconciliation? women's ngos and international intervention in postwar bosnia-herzegovina", Women's Studies International Forum 26, 2003, 15-33

Hyndman, J. \& M. de Alwis, "Reconstituting the Subject: Feminist Politics of Humanitarian Assistance" in M. Hajdukowski-Ahmed, K. Nazilla and H. Moussa, Not Born a Refugee Woman: Contesting Identities, Rethinking Practices, New York \& Oxford:Berghahn Books, 2008

IASC, Women, Girls, Boys and Men: Different Needs, Equal Opportunities. IASC Gender Handbook in Humanitarian Action, 2006, available at http://www.humanitarianinfo.org/iasc/documents/subsidi/tf_gender/IASC\%20Gender $\% 20$ Handbook\%20\%28Feb\%202007\%29.pdf (last visited 3 Jan. 2014)

Jackson, C., "Resolving Risk? Marriage and Creative Conjugality", Development and Change 38(1), 2007, 107-129

Keating, C., C. Rasmussen \& R. Pooja, "The Rationality of Empowerment: Microcredit, Accumulation by Dispossession, and the Gendered Economy", Signs 36(1), 2010, 153176

Kronsell, A., Gender, Sex and the Postnational Defense: Militarism and Peacekeeping:Oxford University Press, 2012

Lang, H., Fear and Sanctuary. Burmese Refugees in Thailand. New York:Cornell Southeast Asia Program, 2002

Larner, W., "Neo-liberalism: Policy, ideology, governmentality." Studies in political economy 63,2000

Larner, W. \& W. Walters, Global governmentality: governing international spaces, London \& New York:Routledge, 2004

Lewa, C., "The Rohingya: Forced Migration and Statelessness" in O. Mishra (ed.) Forced Migration in South Asian Region, Calcutta: Centre for Refugee Studies Jadavpur University

Lewa, C., 'We are like a Soccer Ball, Kicked by Burma, Kicked By Bangladesh!' Rohingya Refugees are Facing a New Drive of Involuntary Repatriation, Bangkok, FORUMASIA, 2003

Lippert, R., "Governing refugees: the relevance of governmentality to understanding the international refugee regime", Alternatives: Global, Local, Political 24(3), 1999, 295328

Madhok, S. \& S. Rai., "Agency, Injury, and Transgressive Politics in Neoliberal Times", Signs 37(3), 2012, 645-669

Mouffe, C., On the Political, London \& New York:Routledge, 2005

Pittaway, E. "The Rohingya Refugees in Bangladesh: A Failure of the International Protection Regime" in H. Adelman (ed.), Protracted displacement in Asia: no place to call home. Aldershot:Ashgate Publishing, 2008

Rankin, K. N., "Governing development: Neoliberalism, microcredit, and rational economic woman." Economy and Society 30(1), 2001, 18-37

Refugees International, Bangladesh - The Silent Crisis, available at http://www.refugeesinternational.org/policy/field-report/bangladesh-silent-crisis (last visited 5 Nov. 2013)

Rose, N. and P. Miller, "Political power beyond the State: problematics of government", The British Journal of Sociology 43(2), 1992, 173-205

Rose, N. and P. Miller, Governing the present: administering economic, social and personal life, Cambridge:Polity Press, 2008 
Rönnblom, M., "Bending towards growth. Discursive constructions of gender equality in an era of governance and neoliberalism" in E. Lombardo, P. Meier and M. Verloo (eds.), The Discursive Politics of Gender Equality. Stretching, Bending and Policymaking, London \& New York:Routledge, 2009, 105-120

Sending, O. J. \& I. B. Neumann, "Governance to Governmentality: Analyzing NGOs, States, and Power", International Studies Quarterly 50(3), 2006, 651-672

Soguk, N., States and strangers: Refugees and displacements of statecraft, Minneapolis:University of Minnesota Press, 1999

South, A., "Karen Nationalist Communities: The 'Problem' of Diversity", Contemporary Southeast Asia: A Journal of International and Strategic Affairs 29(1), 2007, 55-76

South, A., Ethnic Politics in Burma: States of Conflict, London \& New York:Routledge, 2008

TBBC, Between Worlds: Twenty Years on the Border Bangkok, Thailand Burma Border Consortium 2004.

TBBC, TBBC Programme Report January to June 2006, available at http://theborderconsortium.org/resources/2006-6-mth-rpt-jan-jun.pdf (last visit 20 Nov. 2013)

TBBC, TBBC Programme Report July to December 2006 available at http://theborderconsortium.org/resources/2006-6-mth-rpt-jul-dec.pdf (last visit 20 Nov. 2013)

TBBC, TBBC Programme Report July to December 2007, available at http://theborderconsortium.org/resources/2007-6-mth-rpt-jul-dec.pdf (last visit 20 Nov. 2013)

TBBC, TBBC Programme Report January to June 2008, available at http://theborderconsortium.org/resources/2008-6-mth-rpt-jan-jun.pdf (last visit 20 Nov. 2013)

TBC, Refugee and IDP Camp Populations: September 2013, 2013, available at http://theborderconsortium.org/camps/2013-09-sep-map-tbc-unhcr.pdf (last visited 14 Nov. 2013)

Thompson, S. "Community-based Camp Management." Forced Migration Review 30 (Burma's Displaced Peoples), 2008

True, J., "Mainstreaming gender in global public policy", International Feminist Journal of Politics 5(3), 2003, 368-396

Turner, S., "New Opportunities: Angry Young Men in a Tanzanian Refugee Camp" in P. Essed, G. Frerks and J. Schrijvers (eds.), Refugees and the Transformation of Societies. Agency, Policies, Ethics and Politics. New York \& Oxford:Berghahn Books, 2004

UNHCR, Policy on Refugee Women, available at http://www.unhcr.org/3ba6186810.html (last visited 9 Jan. 2014)

UNHCR, Handbook for the Protection of Women and Girls, 2008, available at http://www.unhcr.org/47cfa9fe2.html (last visited 3 Jan. 2014)

UNHCR, UNHCR Bangladesh Fact Sheet September 2013, 2013, available at http://www.unhcr.org/50001ae09.html (last visited 5 Nov. 2013)

UNHCR UNHCR Country Operations Profile 2013 - Thailand, 2013, available at http://www.unhcr.org/cgi-bin/texis/vtx/page?page=49e489646\&submit=GO (last visited 14 Nov. 2013)

WFP, Women and WFP: Helping Women Help Themselves, 2011, available at http://documents.wfp.org/stellent/groups/public/documents/communications/wfp2324 15.pdf (last visited 8 Jan. 2014)

WFP \& UNHCR, Report of the WFP-UNHCR Joint Assessment Mission 15th - 24th June 2008, 2008, available at 
http://documents.wfp.org/stellent/groups/public/documents/ena/wfp190341.pdf (last visited 8 Jan. 2014)

WFP \& UNHCR, Report of the WFP-UNHCR Joint Assessment Mission, Bangladesh 30th May-14th June 2010, 2010, available at http://www.refworld.org/pdfid/4cdd31062.pdf (last visited 8 Jan. 2014) 